\section{INVESTIGATION ON DIELECTRIC AND SOUND ABSORPTION PROPERTIES OF BANANA FIBERS REINFORCED EPOXY COMPOSITES}

Article history

Received

18 December 2015

Received in revised form

10 March 2016

Accepted

25 April 2016

\author{
Elammaran Jayamania*, Sinin Hamdan', Pushparaj \\ Ezhumalaia, Muhammad Khusairy Bakria
}

aFaculty of Engineering, Computing and Science, Swinburne University of Technology Sarawak Campus, Jalan Simpang Tiga, 93350, Kuching, Sarawak, Malaysia.

bDepartment of Mechanical and Manufacturing Engineering, Universiti Malaysia Sarawak, 93400, Kota Samarahan, Sarawak, Malaysia.
*Corresponding author
ejayamani@swinburne.edu.my

\begin{abstract}
This research work focused on the development of banana fiber reinforced epoxy resin composites for dielectric and sound absorption applications. The dielectric and sound absorption properties of the composites were studied with respect to the fiber loading and treatment. The fibers were treated using $5 w t \%$ of sodium hydroxide at room temperature. The properties of the composites were measured using HP Impedance Analyzer E4980A and two-microphone transfer function impedance tube method according to the American Society for Testing Materials (ASTM D150-11 and ASTM E1050-12) standards. In general, the composites displayed higher dielectric constant and sound absorption coefficients at the higher fiber loading. In extend, the treated fibers reinforced composites showed higher sound absorption coefficients, but lower dielectric constant values.
\end{abstract}

Keywords: Banana fiber; sound absorption coefficients; dielectric constant; composites

\begin{abstract}
Abstrak
Hasil kerja penyelidikan ini memberi tumpuan kepada pembangunan komposit daripada resin epoksi yang diperkukuhkan dengan serat pisang untuk aplikasi penyerapan bunyi dan dielektrik. Sifat-sifat komposit dari segi penyerapan bunyi dan dielektrik akan dikaji dari segi kepadatan dan rawatan serat tersebut. Serat akan dirawat dengan menggunakan 5 wt\% natrium hidroksida yang akan dikekalkan dalam suhu bilik. Sifat-sifat komposit akan diukur dengan menggunakan HP Impedance Analyzer E4980 A dan kaedah dua mikrofon pemindahan fungsi galangan tiub berdasarkan standard Persatuan Amerika untuk Ujian Bahan (ASTM D150-11 dan ASTM E1050-12). Secara umum, hasil ujikaji menunjukkan komposit dielektrik mempunyai pemalaran yang tinggi dan penyerapan bunyi yang tinggi untuk kepadatan serat yang tinggi. Secara lanjutan, serat yang dirawat untuk memperkukuhkan komposit menunjukkan penyerapan bunyi yang tinggi, namun mempunyai pemalaran dielektrik yang rendah.
\end{abstract}

Kata kunci: Serat pisang; pekali penyerapan bunyi; pemalar dielektrik; komposit

(C) 2016 Penerbit UTM Press. All rights reserved

\subsection{INTRODUCTION}

Natural fibers reinforced polymer matrix composites have been gaining importance in the automotive, transport, packaging, furniture, and building and construction industries. They have the potential to replace synthetic fibers that exist in above mentioned industries. Natural fibers have specific stiffness which is similar to synthetic fibers, and this makes them attractive as renewable alternative to synthetic fibers. The various advantages of natural fibers over synthetic fibers are recyclability, low cost, renewability, low 